\title{
Editorial
}

\section{Watching Karlsruhe/Karlsruhe Watchers}

The Treaty on Stability, Coordination and Governance in the Economic and Monetary Union, more commonly known as the Fiscal Compact, and the Treaty establishing the European Stability Mechanism (ESM) are closely linked in several ways. Both treaties are formally placed outside the European Union framework, but substantively govern Union matters. Together they are designed to combat the sovereign debt crisis which has been ravaging the European Union for years now. The Fiscal Compact does so by enhancing and sharpening budgetary discipline in the Eurozone states, the ESM Treaty by offering assistance to Eurozone states in financial distress. To receive financial aid from the ESM, states not only need to have ratified the Fiscal Compact, but also to have implemented a balanced budget rule in their national law in the way the Compact demands. ${ }^{1}$ Apart from combating the crisis, the Treaties also bring reforms to the Eurozone; they express the wish of the signatory parties to share their destinies in new ways.

This summer three national constitutional courts ruled on the conformity of these treaties with their national constitutions. The Estonian Riigikohus decided on 12 July 2012 on the ESM Treaty, ${ }^{2}$ the French Conseil constitutionnel on 9 August $2012^{3}$ on the Fiscal Compact and the German Bundesverfassungsgericht on 12 September 2012 on both treaties. ${ }^{4}$ The treaties took the constitutional hurdles before them rather easily. At the time of appearance of this issue of EuConst, the ESM Treaty will have entered into force. As we write these lines, however, the legal battle is not over yet. Although it went further into the merits than is normal

${ }^{1}$ See the 25 th recital in het preamble of the Fiscal Compact en the $5^{\text {th }}$ recital in the preamble of the ESM Treaty.

${ }^{2}$ Constitutional Judgment 3-4-1-6-12, English translation available at <www.riigikohus.ee/? $\mathrm{id}=1347>$.

${ }^{3}$ Decision No. 2012-653 DC, English translation available at <www.conseil-constitution nel.fr/conseil-constitutionnel/english/case-law/decision/decision-no-2012-653-dc-of-9-au gust-2012.115501.html>.

${ }^{4}$ BVerfG, 2 BvR 1390/12, available at <www.bverfg.de/entscheidungen/rs20120912_2bvr 139012.html ; for the English extracts, see <www.bverfg.de/entscheidungen/rs20120912_2bvr1390 12en.html>. 
for summary proceedings, the Bundesverfassungsgericht only rejected demands for temporary injunctions and at least in theory, the findings in the main proceedings might differ from those on 12 September. In addition, the Court of Justice of the European Union still has to rule on the Pringle case, in which the Irish Supreme Court asked the European Court to rule on the compatibility of the ESM Treaty with Union law (Case C-370/12).

Politically speaking however, the die is cast and the treaties are in safe harbour. For whatever the merits of a sharp distinction between constitutional law and politics, neither the Bundesverfassungsgericht nor the Court of Justice, nor any other court, is in a position to block or hamper the treaties any more - and perhaps they never were. The political (and financial) stakes are simply too high.

The rulings of the Riigikohus and the Conseil constitutionnel will be the subject of commentaries in the next issue. Let us now concentrate on the Bundesverfassungsgericht ruling on the Fiscal Compact and the ESM Treaty of 12 September 2012.

The part of the ruling that received the least public attention concerns the Fiscal Compact. The Court itself did not even find it necessary to include its considerations on the Compact in the extracts of the judgment which were translated into English and which were made available on the Constitutional Court's website immediately after the pronouncement of the judgment on 12 September, together with the German original. ${ }^{5}$ This probably reflects the ease with which the German Court was able to reject the complaints against the Compact.

The Court found that the balanced budget rule, the independent budget supervisor and the automatic correction mechanism which the Compact requires the ratifying Eurozone states to install in their national law (Article 3(2)) ${ }^{6}$ were essentially similar to national rules already adopted in Germany in 2009 in respectively the Grundgesetz (Article 109(3)), the Stabilitätsratsgesetz and the accompanying Ausführungsgesetz (paragraphs 305-308 German original). What was easily refuted was the complaint that ratification of the Compact would impose the irreversible obligation on Germany to maintain the 'Schuldenbremse' in the German Constitution due to the absence of a cancellation clause, thus depriving German politics of the possibility of opting for another financial-economic policy. All treaties may be ended by mutual consent of the contracting states and unilateral withdrawal is possible if the circumstances change fundamentally in the sense of Article 62 of the Vienna Convention on the Law of Treaties. Indeed: withdrawal from the EU and/or the common currency would take away the foundation for further compliance with the obligations to which EU member states have com-

\footnotetext{
${ }^{5}$ Idem.

${ }^{6}$ For an analysis of these, see Peers' contribution in this issue.
} 
mitted themselves in the Compact (paragraph 319, German original). The most interesting section of this part of the judgment is the Court's neutralizing interpretation of the powers of the European Commission regarding the automatic correction mechanism by which significant deviations from the balanced budget rule have to be corrected according to the Compact. Article 3(2) of the Compact obliges the Eurozone states to implement this mechanism 'on the basis of common principles to be proposed by the European Commission, concerning in particular the nature, the size and the time-frame of the corrective action to be undertaken'. However, the same article adds that 'This mechanism shall fully respect the prerogatives of national Parliaments', Therefore, according to the German Court, the powers of the Commission are limited to institutional provisions and do not include the power to issue directives regarding substantive budgetary issues ('keine Befugnis zu konkreten materiellen Vorgaben für die Gestaltung der Haushalte' (paragraph 315 German original)). ${ }^{7}$ If it would have been otherwise, a part of the 'Budgetverantwortung' of the Bundestag would have passed to the Commission, which would have made the Compact unconstitutional (see infra).

This brings us to the heart of the reasoning regarding the ESM Treaty. It is based on the mandatory overall budgetary responsibility of the Bundestag towards the German people. This responsibility springs from the right to elect the members of the Bundestag (Article 38(1) Grundgesetz), 'a right equivalent to a fundamental right', which guarantees citizens' self-determination and the free and equal participation in the exercise of German state authority; these principles belong to the German constitutional identity and are protected by the 'eternity clause' in Article 79(3) Grundgesetz (paragraph 208 German original; 192 English translation).

The overall budgetary responsibility implies inter alia that the Bundestag must take its budgetary decisions free from outside directives (Fremdbestimmung) by EU institutions (paragraph 213 German original, 197 English translation) - this accounts for the aforementioned neutralizing interpretation regarding the powers of the Commission under the Fiscal Compact. It moreover prohibits the Bundestag to imperil its or a future Bundestag's budgetary competences by giving 'other institutions' the competence to take decisions which could 'result in incalculable burdens with budget significance without prior mandatory consent, whether these are expenses or losses of revenue' (paragraph 212 German original, 196 English translation).

\footnotetext{
${ }^{7}$ In the same vein the Conseil constitutionnel, supra n. 3, para. 25; this obviously also is the view of the European Commission itself, because in the principles which it 'proposed' on 26 June 2012 ('Common principles on national fiscal correction mechanisms', COM(2012)342 final) such substantive directives are lacking.
} 
The same overall budgetary responsibility also prohibits the creation under international law of permanent mechanisms under which Germany assumes liability for the free behaviour of other states, at least if the financial consequences are hard to calculate. And if, in solidarity with other (Eurozone-)states, an international agreement is entered into which in one way or another foresees large scale financial aid measures with possibly structural consequences for the Bundestag's budgetary autonomy, it must not only be assured that 'every individual disposal requires the consent of the Bundestag', but also that there is sufficient and continued parliamentary influence on the way the funds provided are handled by the receiving states (paragraph 214 German original, 198 English translation).

In the Bundesverfassungsgericht's view, the ESM actually conforms to all these conditions, inter alia because the Bundestag in the Act approving the Treaty and in the 'Gesetz zur finanziellen Beteiligung am Europäischen Stabilitätsmechanismus' [Act on Financial Participation in the ESM] had already bestowed upon itself in principle the constitutionally required powers of decision. But for certainty's sake, the German Court also formulated two interpretative provisos, intended to clarify the terms of the contract before it enters into force.

In the interpretation of the German Court, the Treaty clearly limits the liability of Germany for the financial transactions of the ESM under all circumstances to a maximum of 190 billion euros, the German portion of the authorized capital stock of the ESM; any increase of that portion would require a new decision of the Bundestag. ${ }^{8}$ This was also the assumption of the Bundestag when it approved the Treaty. On basis of arguments advanced at the oral hearing, the German Court could not, however, totally exclude that the ESM institutions and finally the Court of Justice, the ultimate interpreter of the Treaty (Article 37(3)), would adopt the different view that the German portion could be raised under certain circumstances by the ESM itself, without the Bundestag having a veto power. To prevent this interpretation, the Court obliged the German president to make an interpretative reservation in the framework of the ratification procedure, to which the government would have to add the formula that if the alternative interpretation were nevertheless to be adopted, Germany would not be bound by the ESM at all (paragraphs 239-253 German original, 208-222 English version).

The Court obliged the German president to make a similar reservation to ensure that the professional secrecy imposed on and the immunities given to members of the ESM executive, including the national finance ministers in the Board of Governors, cannot be invoked vis-à-vis the Bundestag: information by the government on (proposed) ESM action is, according to the Court, a sine qua non for the exercise of the Bundestag's monitoring function and its budgetary responsibility; ' $(t)$ he core of the right of parliament to be informed is therefore also entrenched

\footnotetext{
${ }^{8}$ This is also the interpretation of the Riigikohus, supra n. 2, para. 144.
} 
in Article 79(3) of the Basic Law' (paragraphs 215, 254-259 German original, 199, 223-228 English translation).

This formula of required reservations, at first sight, is unnecessarily cumbersome and threatening:' if the reservation is not effective, the whole Treaty is up in the air. ${ }^{10}$ However, the formula is not only due to the fundamental constitutional nature of the provisos, but also to international law requirements, more specifically Article 20(2) and (3) of the Vienna Convention on the Law of Treaties. Because the ESM Treaty (1) does not expressly authorize reservations, (2) the object and purpose of the ESM Treaty is that the application of the treaty in its entirety between all the parties is an essential condition of the consent of each one to be bound by the treaty' and (3) the ESM Treaty is 'the constituent instrument of an international organization', reservations, to be effective, not only require the consent of the other contracting states but also of the 'competent organ of that organization'. In short, the threat of blowing up the whole ESM will force the other contracting parties and the competent ESM institution (the Board of Governors?) to accept the reservations.

The yardstick by which the Bundesverfassungsgericht judges the ESM Treaty is not new. It is firmly rooted in previous case law and specifically in the decision of 7 September 2011 on the 'Euro rescue package. ${ }^{11}$ But what does it have to say about the future? Allow us to very briefly raise three points.

The first is that the judgment makes crystal-clear that the 190 billion for which Germany assumes liability under the ESM Treaty is not the end of the story. The sum may be raised, if the Bundestag consents to it and if the extra funds do not endanger the budget autonomy of the Bundestag, directly or in the future.

The second point concerns the decision of the European Central Bank of 6 September 2012 to buy government obligations of troubled Eurozone states on the secondary markets - if necessary ad infinitum. On 12 September 2012 the Bundesverfassungsgericht did not rule on the complaint that the Bank thereby acted ultra vires - it will do so later (paragraph 202 of the German original). Nevertheless, at first sight the case seems already to have been decided on 12 September. In one of its arguments, the Court reasons that Article 123 TFEU not only forbids the European Central Bank to buy government bonds on the primary markets, but also on the secondary markets: otherwise the prohibition of monetary

${ }^{9}$ Para. 253: 'Die Bundesrepublik Deutschland muss deutlich zum Ausdruck bringen, dass sie an den ESM-Vertrag insgesamt nicht gebunden sein kann, falls sich der von ihr geltend gemachte Vorbehalt als unwirksam erweisen sollte'.

${ }^{10}$ Without Germany's participation the ESM not only substantively, but also formerly cannot function; see Art. 48 ESM-Treaty.

${ }^{11}$ BVerfG,2BvR987/10, availableat<www.bverfg.de/entscheidungen/rs20110907_2bvr098710. html>; see the case-note of Antje von Ungern-Sternberg in EuConst (2012) p. 304. 
financing could be bypassed. However, on closer examination the argument reveals that such purchasing on the secondary markets is only prohibited if it is aimed at financing national economies independent from the capital markets. ${ }^{12}$ Now even if that is the (temporary) effect of the European Central Bank's interventions, if they ever materialize, it is not their aim. Their aim is to secure 'price stability over the medium term', ${ }^{13}$ which, it should be noted, does not exclude that the interventions have inflationary effects in the long run. However, if the Bundesverfassungsgericht finds the argument of the European Central Bank to be not implausible and leaves the Bank as much leeway as it has given the Court of Justice in the Honeywell case, ${ }^{14}$ the Bank's decision must be expected to pass and the ultra vires complaint to be rejected (if declared admissible at all). ${ }^{15}$

The third point relates to the structure of the stability community which the monetary Union is and should remain: the overall budgetary responsibility of the Bundestag is protected at the Union level by, among other things, the independence of the European Central Bank, the priority of price stability and the prohibition of monetary financing by the European Central Bank. The existence of such safeguards, therefore, is a constitutional requirement ex the Article 79(3) Grundgesetz for Germany's participation in the EU. However, the Bundesverfassungsgericht continues by saying that Article 79(3) Grundgesetz does not require that no single element of the stability community may be altered (paragraphs 220-221 German original, 204-205 English translation): the structure of the stability community may evolve, albeit on the condition of respect for the Bundestag's overall budgetary responsibility:

Already in its Maastricht judgment, the Federal Constitutional Court held that, in order to comply with the stability mandate, a continuous further development of the monetary union may be necessary if otherwise the conception of the monetary union, which had been designed as a stability union, would be departed from (...). If the monetary union cannot be achieved in its original structure through the valid integration programme, new political decisions are needed as to how to proceed further (...). It is for the legislature to decide how possible weaknesses of the mon-

${ }^{12}$ 'Denn ein Erwerb von Staatsanleihen am Sekundärmarkt durch die Europäische Zentralbank, der auf von den Kapitalmärkten unabhängige Finanzierung der Haushalte der Mitgliedstaaten zielte, ist als Umgehung des Verbotes monetärer Haushaltsfinanzierung ebenfalls untersagt'; para. 278 German original, 247 English translation.

${ }^{13}$ Mario Draghi. Introductory statement to the press conference in Frankfurt am Main on 6 Sept. 2012.

${ }^{14}$ BVerfG, 2 BvR 2661/06, decision of 6 July 2010, see <www.bverfg.de/entscheidungen/ rs20100706_2bvr266106en.html>.

${ }^{15}$ For this it is required that the interventions lead to an obvious depreciation of the currency ('einer evidenten Minderung des Geldwerts'; para. 200 German original), which is not obvious. 
etary union are to be counteracted by amending European Union law. (paragraph 222 German original, 206 English translation)

It is on the basis of this passage that the German Court accepted the introduction of Article 136(3) TFEU, which authorizes the Eurozone states to 'establish a stability mechanism to be activated if indispensable to safeguard the stability of the euro area as a whole. The granting of any required financial assistance under the mechanism will be made subject to strict conditionality'. In exceptional circumstances this provision, as the German Court notes, puts into perspective the independence of the national budgets and the connected principle that the Eurozone states should have recourse to the markets for financing their deficits, principles which have characterized the monetary union so far, in order to safeguard the stability of the Eurozone as a whole (paragraphs 232, 233 German original). This decision of the legislator to stabilize and at the same time develop the monetary union by such means, which leaves other elements of the stability community intact (ECB's mandate to prioritize price stability, the duty of budgetary discipline and dependency on the financial markets under normal circumstances), on principle must be respected by the Bundesverfassungsgericht, even if it involves certain risks for price stability (paragraph 234, German original).

The tone is markedly different from that in the Maastricht Urteil. Although that decision, as the quotation here above shows, already contained considerations giving politics the possibility of restructuring the monetary union, it was overshadowed by mistrust of politics in the monetary field, witness the Court's support for the philosophy to 'withdraw monetary matters from the reach of interests groups and holders of political office concerned about re-election'. ${ }^{16}$

The judgment of 12 September 2012 can be read in two ways: in the key of continuity or in that of a turn. Reading the ESM Urteil in the key of continuity stresses the Court's repeated leveraging of its constitution to empower the German, and more generally, the member states ${ }^{17}$ parliamentary bodies. Reading it as a turn stresses the opening to politics ('the legislator') in the development of the EMU beyond its original parameters. Even the notion of 'Stability Community', central to the EMU in the German view, should be allowed to evolve, to include elements of solidarity.

${ }^{16}$ BVerGE 89, 155 (208).

${ }^{17}$ See for instance para. 256 German original, 225 English translation: 'If in one of its Member States, decisions of the European Stability Mechanism require to be dealt with not only at government level, to which the necessary information is always available, but also to be discussed and approved in parliamentary bodies, it is absolutely necessary for the latter to be informed as well'. 
Which of the two readings is the best, only the Court itself will tell in future rulings. If we are to draw from this ruling and from the situation in which it is handed-down one topic for further research, it is that of the institutional autonomy of judicial and other bodies in a constitutional setting. We have just used the term of 'constitutional leverage'. The Bundesverfassungsgericht does not use its institutional autonomy in a vacuum. It pushes, it directs, it influences. As the president of the German Court, Andreas Vosskuhle, stated in a public debate on 21 September 2012, the ESM judgment also aims to advance the thinking about alternatives. ${ }^{18}$ So how is this to fit in with the Court's autonomy, independence, impartiality?

The idea that its autonomy should consist in not being influenced by nor influencing the political situation in which it acts, is untenable as we all know. The German Court sees itself not (only) as a neutral arbiter but (also) as a player in a game, at both the national and international level. In this it follows the line of other constitutional courts and even the Court of Justice. ${ }^{19}$

Such open involvement in political processes of bodies meant for non-political action may pose no fundamental problem to those involved in practice. They see it as necessary and creative. It does pose questions for doctrinal constitutional thinking and should be immensely inspired by the instances of legal and monetary leveraging currently developed in the euro-crisis. Who will undertake this new study on the meaning of institutional autonomy in the politics of the Union?

JHR/WTE

\footnotetext{
${ }^{18}$ See Wolfgang Janisch, 'Das Europa der Anderen' [The Europe of the Others], Süddeutsche Zeitung, 22/23 Sept. 2012, p. 7.

${ }^{19}$ Very overt in this respect is the decision of the President of the General Court of the EU to suspend the operation of the Commission decision ordering the recovery of 425 million euros from Greek Farmers in Case T-52/12R: 'In the light of the extremely difficult general financial situation in Greece, it is easy to foresee that a significant proportion of the 800000 beneficiaries would refuse to pay voluntarily the sums demanded, necessitating massive intervention on the part of the tax authorities' staff. It is evident that such forcible large-scale collection of tax would prevent the tax authorities to an appreciable extent from devoting themselves to one of their priorities, namely combating tax avoidance and collecting sums shielded from tax that are nearly 100 times greater than the contested payments. In addition, it is common knowledge that a deterioration of confidence in the public authorities, generalised discontent and a feeling of injustice are features of the current social climate in Greece. In particular, violent demonstrations against the draconian austerity measures adopted by the Greek public authorities are constantly increasing. In those circumstances, the risk that the immediate recovery of the contested payments in the entire agricultural sector may trigger demonstrations liable to degenerate into violence appears neither purely hypothetical nor theoretical or uncertain', Press Release 118/12, <curia.europa.eu/jcms/upload/ docs/application/pdf/2012-09/cp120118en.pdf> (visited 2 Oct. 2012).
} 